\title{
KAJIAN YURIDIS MENGENAI PERAMPASAN ASET KORUPSI DALAM UPAYA PEMBERANTASAN TINDAK PIDANA KORUPSI MENURUT HUKUM PIDANA INDONESIA
}

\author{
Oleh : \\ Agus Pranoto* \\ Abadi B Darmo * \\ Iman Hidayat*
}

\begin{abstract}
ABSTRAK
Pengaturan tentang perampasan aset korupsi dalam upaya pemberantasan tindak pidana korupsi menurut hukum pidana Indonesia, diatur di dalam Pasal 18 UndangUndang Pemberantasan Tindak Pidana Korupsi. Norma hukum perampasan aset korupsi merupakan upaya hukum yang paling bersifat strategis, karena apabila ketentuan mengenai sanksi pidana perampasan aset korupsi dapat diterapkan secara efektif, maka upaya pengembalian kerugian negara akibat tindak pidana korupsi, akan mencapai hasilnya secara optimal. Namun demikian, ketentuan mengenai sanksi pidana perampasan aset korupsi tersebut, sulit untuk dapat diterapkan secara efektif, karena terdapat sejumlah kelemahan yang menjadi faktor penghambat penerapannya sehingga diperlukan kebijakan hukum pidana yang sebaiknya dinormakan di dalam Undang-Undang Pemberantasan Tindak Pidana Korupsi mengenai norma hukum yang mengatur secara jelas dan tegas, tentang kedudukan pidana perampasan aset korupsi sebagai bagian dari pidana pokok, standar atau perhitungan kerugian negara dan instansi yang berwenang menetapkan kerugian negara akibat tindak pidana korupsi, dan percepatan penyitaan harta benda milik tersangka korupsi.
\end{abstract}

Kata Kunci: Perampasan Aset Korupsi, Pemberantasan, Hukum Pidana Indonesia

\section{A. Latar Belakang Masalah}

Salah satu tindak pidana yang tergolong fenomenal saat ini adalah kejahatan korupsi. Tindak pidana ini tidak saja merugikan keuangan negara, tetapi juga merupakan pelanggaran terhadap hak-hak sosial dan ekonomi masyarakat. Korupsi telah menghancurkan sendi-sendi agama, nilai-nilai moral dan etika. Ia telah pula menggadaikan marwah bangsa, menjerumuskan Indonesia menjadi bangsa yang terbelakang, miskin dan dililit hutang. Uang rakyat bernilai ribuan triliun rupiah yang seyogyanya dipergunakan untuk mengentaskan kemiskinan dan pengangguran, menciptakan lapangan kerja, menggerakkan sektor riil dan meningkatkan daya saing bangsa, justeru masuk ke kantungkantung pejabat yang korup. Mereka menikmati kehidupan yang mewah, berlimpah dan

\footnotetext{
* ASN di Pemkab Tanjung Jabung Timur, Alumni Program Magister Ilmu Hukum Unbari.

* Pengajar Program Magister Ilmu Hukum Unbari.

* Pengajar Program Magister Ilmu Hukum Unbari.
} 
serba mudah di tengah jeritan ratusan juta rakyat yang hidup dalam tekanan ekonomi yang tidak terperikan.

Di sisi lain, korupsi telah meluluh-lantakkan budaya malu di kalangan penyelenggara negara sehingga menganggap korupsi sebagai tradisi. Bila kondisi ini terus berkembang, dapat dibayangkan betapa seriusnya akibat yang akan ditimbulkannya. Kesenjangan kehidupan akan terus meningkat dan semakin mencolok dan pada gilirannya dapat berubah menjadi ledakan kecemburuan sosial yang amat membahayakan stabilitas keamanan negara.

Dengan demikian, sudah jelas bahwa tindak pidana korupsi tidak lagi dapat digolongkan sebagai kejahatan biasa yang dapat diberantas dengan cara-cara yang konvensional. Ditinjau dari karakteristiknya, korupsi telah menjadi suatu kejahatan khusus yang bersifat luar biasa (extra ordinary crime) sehingga memerlukan upaya pemberantasan secara luar biasa pula.

Oleh karena itu, diperlukan kebijakan hukum pidana atau kebijakan penanggulangan kejahatan, melalui perundang-undangan pidana yang secara jelas dan tegas, mengatur tentang bagaimana tindak pidana korupsi yang kronis tersebut, dapat diberantas secara luar biasa (extra ordinary measures), sistemik dan komprehensif.

Dalam perspektif hukum pidana Indonesia, tindak pidana korupsi diatur dalam Undang-undang Nomor 31 tahun 1999 tentang Pemberantasan Tindak Pidana Korupsi sebagaimana telah diubah dengan Undang-undang Nomor 20 tahun 2001 tentang Perubahan atas Undang-undang Nomor 31 tahun 1999 tentang Pemberantasan Tindak Pidana Korupsi.

Undang-undang Nomor 31 tahun 1999 tentang Pemberantasan Tindak Pidana Korupsi, lahir dari kesadaran bahwa tindak pidana korupsi sangat merugikan keuangan negara atau perekonomian negara dan menghambat pembangunan nasional, sehingga harus diberantas dalam rangka mewujudkan masyarakat adil dan makmur berdasarkan Pancasila dan Undang-Undang Dasar 1945, akibat tindak pidana korupsi yang terjadi selama ini selain merugikan keuangan negara atau perekonomian negara, juga menghambat pertumbuhan dan kelangsungan pembangunan nasional yang menuntut efisiensi tinggi dan bahwa Undang-undang Nomor 3 Tahun 1971 tentang Pemberantasan Tindak Pidana Korupsi sudah tidak sesuai lagi dengan perkembangan kebutuhan hukum dalam masyarakat, karena itu perlu diganti dengan Undang-undang Pemberantasan Tindak Pidana 
Korupsi yang baru sehingga diharapkan lebih efektif dalam mencegah dan memberantas tindak pidana korupsi.

Selanjutnya Undang-Undang Nomor 20 tahun 2001 tentang Perubahan atas Undang-Undang Nomor 31 tahun 1999 tentang Pemberantasan Tindak Pidana Korupsi (Selanjutnya disebut Undang-Undang Pemberantasan Tindak Pidana Korupsi), diundangkan berdasarkan pertimbangan bahwa tindak pidana korupsi yang selama ini terjadi secara meluas, tidak hanya merugikan keuangan negara, tetapi juga telah merupakan pelanggaran terhadap hak-hak sosial dan ekonomi masyarakat secara luas, sehingga tindak pidana korupsi perlu digolongkan sebagai kejahatan yang pemberantasannya harus dilakukan secara luar biasa

Di samping itu, perubahan atas Undang-Undang Nomor 31 Tahun 1999 tentang Pemberantasan Tindak Pidana Korupsi. perlu dilakukan untuk menghindari keragaman penafsiran hukum dan memberikan perlindungan terhadap hak-hak sosial dan ekonomi masyarakat, serta perlakuan secara adil dalam memberantas tindak pidana korupsi.

Upaya pemberantasan secara luar biasa terhadap tindak pidana korupsi sebagaimana disebut dalam dasar pertimbangan lahirnya Pemberantasan Tindak Pidana Korupsi, antara lain diwujudkan melalui perumusan ketentuan yang mengatur mengenai jenis sanksi pidana yang tidak ditemukan dalam Undang-Undang pidana lainnya. Sanksi pidana dimaksud adalah sanksi pidana tambahan berupa perampasan barang bergerak yang berwujud atau yang tidak berwujud atau barang tidak bergerak yang digunakan untuk atau yang diperoleh dari tindak pidana korupsi.

Ketentuan mengenai sanksi pidana perampasan asset yang diperoleh dari tindak pidana korupsi, termaktub di dalam Pasal 18 Undang-Undang Pemberantasan Tindak Pidana Korupsi, yang selengkapnya menggariskan bahwa:

Pasal 18

(1). Selain pidana tambahan sebagaimana dimaksud dalam Kitab Undang-undang Hukum Pidana, sebagai pidana tambahan adalah:

a. perampasan barang bergerak yang berwujud atau yang tidak berwujud atau barang tidak bergerak yang digunakan untuk atau yang diperoleh dari tindak pidana korupsi, termasuk perusahaan milik terpidana di mana tindak pidana korupsi dilakukan, begitu pula dari barang yang mengantikan barang-barang tersebut; 
b. pembayaran uang pengganti yang jumlahnya sebanyak-banyaknya sama dengan harta benda yang diperoleh dari tindak pidana korupsi.

c. Penutupan Seluruh atau sebagian perusahaan untuk waktu paling lama 1 (satu) tahun;

d. Pencabutan seluruh atau sebagian hak-hak tertentu atau penghapusan seluruh atau sebagian keuntungan tertentu, yang telah atau dapat diberikan oleh Pemerintah kepada terpidana.

(2) Jika terpidana tidak membayar uang pengganti sebagaimana dimaksud dalam ayat (1) huruf b paling lama dalam waktu 1 (satu) bulan sesudah putusan pengadilan yang telah memperoleh kekuatan hukum tetap, maka harta bendanya dapat disita oleh jaksa dan dilelang untuk menutupi uang pengganti tersebut.

(3). Dalam hal terpidana tidak mempunyai harta benda yang mencukupi untuk membayar uang pengganti sebagaimana dimaksud dalam ayat (1) huruf $b$, maka dipidana dengan pidana penjara yang lamanya tidak melebihi ancaman maksimum dari pidana pokoknya sesuai dengan ketentuan dalam Undangundang ini dan lamanya pidana tersebut sudah ditentukan dalam putusan pengadilan.

Apabila ditinjau dari sudut normatif, ketentuan tersebut di atas menimbulkan harapan yang cukup besar akan terjadinya pemberantasan tindak pidana korupsi secara sistemik dan komprehensif, yang tidak saja ditandai dengan dijatuhkannya hukuman terhadap pelaku tindak pidana atas perbuatannya mengkorupsi uang negara, tetapi juga harapan akan adanya penyelamatan uang negara yang ditandai dengan perampasan asset yang diperoleh dari korupsi, untuk kemudian dapat dipergunakan sebesar-besarnya bagi kepentingan pembangunan nasional.

Dengan demikian, dapat dikatakan bahwa secara normatif ketentuan Pasal 18 ayat (1) huruf a Undang-Undang Pemberantasan Tindak Pidana Korupsi, diharapkan dapat menjadi sarana hukum yang efektif untuk pemulihan kerugian negara akibat tindak pidana korupsi.

Selanjutnya bila dikaitkan dengan tujuan hukum, maka ketentuan Pasal 18 ayat (1) huruf a Undang-Undang Pemberantasan Tindak Pidana Korupsi tersebut, merupakan sarana yang tepat bagi pencapaian tujuan ditegakkannya hukum yakni tercapainya asas kemanfaatan, dimana ketentuan tersebut akan sangat bermanfaat bagi penyelamatan uang negara demi kepentingan masyarakat dalam arti yang seluas-luasnya. 
Meski secara normatif membawa harapan yang besar, namun dalam tataran implementatif ketentuan tersebut tampaknya belum sepenuhnya dapat diwujudkan. Hal itu antara lain dapat dilihat pada data kerugian negara akibat tindak pidana korupsi yang berhasil diungkap oleh institusi penegak hukum yakni Kejaksaan dan Komisi Pemberantasan Korupsi (KPK), selama kurun waktu dua tahun terakhir yakni tahun 2010 sampai dengan 2011. Indonesian Corruption Watch (ICW) merilis bahwa dalam kurun waktu tersebut, jumlah kerugian negara akibat korupsi mencapai lebih kurang Rp. 8.5 triliun. Dari kerugian negara sebesar itu, yang berhasil diselamatkan dan dikembalikan ke kas negara, masih tergolong sangat kecil yakni hanya sekitar Rp. 1.2 triliun saja. ${ }^{1}$

Mencermati kinerja penegakan hukum terhadap tindak pidana korupsi, terutama kinerja pengembalian kerugian negara di atas, disimpulkan bahwa ketentuan Pasal 18 ayat (1) huruf a Undang-Undang Pemberantasan Tindak Pidana Korupsi, belum mampu menjadi sarana hukum yang efektif untuk memastikan bahwa pada setiap penyelesaian perkara korupsi, benar-benar akan terjadi pengembalian kerugian negara.

Berdasarkan studi pendahuluan, ketidakmampuan Pasal 18 ayat (1) huruf a Undang-Undang Pemberantasan Tindak Pidana Korupsi, terutama ketentuan yang mengatur perampasan asset korupsi, menjadi sarana hukum yang efektif dalam pengembalian kerugian negara tersebut, diduga terjadi karena adanya kelemahan dalam perumusan ketentuan pasal dimaksud. Kelemahan dimaksud adalah karena kedudukan pasal tersebut yang hanya merupakan pidana tambahan atau bukan sebagai pidana pokok.

Di samping itu, terdapat pula kekaburan norma atau norma yang tidak jelas (unclear norm/vague van normen) di dalam Pasal 18 ayat (1) huruf a Undang-Undang Pemberantasan Tindak Pidana Korupsi, sedemikian sehingga ketentuan Pasal 18 ayat (1) huruf a, tidak memuat ketentuan yang jelas dan tegas tentang kriteria, batasan-batasan, atau aset yang bagaimana yang dapat dirampas dari orang yang disangka telah melakukan tindak pidana korupsi.

Kekaburan norma tersebut, menyebabkan penegak hukum di lapangan memiliki tafsir yang berbeda dalam hal perampasan aset korupsi, sedemikian sehingga terjadi keragu-raguan dalam diri penegak hukum untuk melakukan perampasan aset dari tersangka pelaku tindak pidana korupsi, yang pada akhirnya bermuara pada rendahnya kinerja pengembalian kerugian negara akibat kejahatan korupsi.

\footnotetext{
${ }^{1}$ www.vivanews.com/diakses pada tanggal 4 Juli 2014
} 


\section{B. Perumusan Masalah}

Berdasarkan latar belakang yang telah penulis paparkan diatas, maka penulis merumuskan pokok permasalahan sebagai berikut :

1. Bagaimanakah pengaturan tentang perampasan aset korupsi dalam Pasal 18 dalam upaya pemberantasan tindak pidana korupsi menurut hukum pidana Indonesia?;

2. Faktor-faktor apa saja yang sebaiknya dinormakan agar perampasan aset korupsi dapat menjamin pengembalian kerugian negara akibat tindak pidana korupsi?.

\section{Metode Penelitian}

1. Tipe Penelitian

Tipe penelitian yang digunakan adalah yuridis normatif yaitu suatu tipe penelitian yang menelaah berbagai peraturan perundang-undangan dan berbagai literatur yang berhubungan dengan ketentuan perundang-undangan yang mengatur mengenai pengembalian kerugian negara dalam tindak pidana korupsi.

\section{Pendekatan yang Digunakan}

Berdasarkan tipe penelitian normatif tersebut di atas, maka pendekatan yang digunakan dalam penelitian ini adalah pendekatan konseptual (conceptual approach), pendekatan perundang-undangan (normative approach). Terkait dengan pendekatan tersebut, dalam penelitian ini akan digambarkan tentang hal-hal yang berkaitan dengan tindak pidana korupsi dan pengembalian uang negara dalam tindak pidana korupsi.

\section{Tinjauan yuridis mengenai perampasan asset korupsi dalam upaya pemberantasan tindak pidana korupsi menurut hukum pidana Indonesia}

1. Pengaturan tentang perampasan aset korupsi dalam Pasal 18 dalam upaya pemberantasan tindak pidana korupsi menurut hukum pidana Indonesia

Sebagaimana telah disinggung di muka, bahwa dalam rangka melakukan pemberantasan terhadap tindak pidana korupsi sebagai kejahatan luar biasa, maka di dalam Undang-Undang Pemberantasan Tindak Pidana Korupsi, dirumuskan norma hukum baru yang bersifat spesifik yakni norma pengembalian kerugian negara akibat tindak pidana korupsi.

Norma pengembalian kerugian negara, sebagai bagian dari sanksi pidana yang dapat dibebankan kepada pelaku tindak pidana korupsi, adalah berupa perampasan aset korupsi dan pembayaran uang pengganti. Hal itu diatur di dalam Pasal 18 Undang-Undang 
Pemberantasan Tindak Pidana Korupsi. Norma tersebut merupakan bagian integral dari upaya negara memulihkan keuangan negara yang terjadi akibat tindak pidana korupsi.

Upaya lain yang diatur di dalam Undang-Undang Pemberantasan Tindak pidana Korupsi, adalah upaya hukum perdata. Upaya hukum dimaksud diwujudkan melalui gugatan perdata kepada ahli waris, apabila tersangka korupsi meninggal dunia di dalam penyidikan, dan gugatan perdata kepada terpidana atau ahli warisnya, apabila dikemudian hari ditemukan adanya harta terpidana yang diduga kuat berasal dari tindak pidana korupsi.

Pengaturan mengenai gugatan perdata kepada ahli waris apabila tersangka korupsi yang meninggal dunia dalam penyidikan, diatur dalam Pasal 33 Undang-undang Pemberantasan Tipikor, yang pada intinya menyatakan bahwa "Dalam hal tersangka meninggal dunia pada saat dilakukan penyidikan, sedangkan secara nyata telah ada kerugian keuangan negara, maka penyidik segera menyerahkan berkas perkara hasil penyidikan tersebut kepada Jaksa Pengacara Negara atau diserahkan kepada instansi yang dirugikan untuk dilakukan gugatan perdata terhadap ahli warisnya".

Dalam Undang-Undang Pemberantasan Tindak pidana Korupsi, diatur pula hak negara untuk mengajukan gugatan perdata terhadap harta benda terpidana yang disembunyikan atau tersembunyi dan baru diketahui setelah putusan pengadilan memperoleh kekuatan hukum tetap. Harta benda yang disembunyikan atau tersembunyi tersebut diduga atau patut diduga berasal dari tindak pidanakorupsi. Gugatan perdata dilakukan terhadap terpidana dan atau ahli warisnya. Untuk melakukan gugatan tersebut, negara dapat menunjuk kuasanya untuk mewakili negara.

Ketentuan tersebut diatur dalam Pasal $38 \mathrm{C}$, yang selengkapnya menggariskan bahwa:

Apabila setelah putusan pengadilan telah memperoleh kekuatan hukum tetap, diketahui masih terdapat harta benda milik terpidana yang diduga atau patut diduga juga berasal dari tindak pidana korupsi yang belum dikenakan perampasan untuk negara sebagaimana dimaksud dalam Pasal 38 B ayat (2), maka negara dapat melakukan gugatan perdata terhadap terpidana dan atau ahli warisnya.

Berdasarkan ketentuan yang mengatur mengenai upaya pengembalian kerugian negara akibat tindak pidana korupsi tersebut di atas, disimpulkan bahwa norma pengembalian kerugian negara di dalam Undang-Undang Pemberantasan Tindak Pidana Korupsi, terdiri dari norma hukum pidana dan norma hukum perdata. Norma hukum pidana diwujudkan melalui perumusan sanksi pidana berupa perampasan aset korupsi dan 
pidana pembayaran uang pengganti. Sementara norma hukum perdata adalah mencakup gugatan perdata kepada ahli waris apabila tersangka korupsi meninggal dunia di dalam penyidikan, dan gugatan perdata kepada terpidana atau ahli warisnya, apabila dikemudian hari ditemukan adanya harta terpidana yang diduga kuat berasal dari tindak pidana korupsi.

Terkait dengan upaya hukum pidana berupa sanksi pidana pembayaran uang pengganti, Pasal 18 Undang-Undang Pemberantasan Tindak Pidana Korupsi mengamanatkan bahwa:

Pasal 18

(1). Selain pidana tambahan sebagaimana dimaksud dalam Kitab Undang-Undang Hukum Pidana, sebagai pidana tambahan adalah:

a. perampasan barang bergerak yang berwujud atau yang tidak berwujud atau barang tidak bergerak yang digunakan untuk atau yang diperoleh dari tindak pidana korupsi, termasuk perusahaan milik terpidana dimana tindak pidana korupsi dilakukan, begitu pula dari barang yang mengantikan barang-barang tersebut;

b. pembayaran uang pengganti yang jumlahnya sebanyak-banyaknya sama dengan harta benda yang diperoleh dari tindak pidana korupsi.

c. Penutupan seluruh atau sebagian perusahaan untuk waktu paling lama 1 (satu) tahun;

d. Pencabutan seluruh atau sebagian hak-hak tertentu atau penghapusan seluruh atau sebagian keuntungan tertentu, yang telah atau dapat diberikan oleh Pemerintah kepada terpidana.

(2) Jika terpidana tidak membayar uang pengganti sebagaimana dimaksud dalam ayat (1) huruf b paling lama dalam waktu 1 (satu) bulan sesudah putusan pengadilan yang telah memperoleh kekuatan hukum tetap, maka harta bendanya dapat disita oleh jaksa dan dilelang untuk menutupi uang pengganti tersebut.

(3) Dalam hal terpidana tidak mempunyai harta benda yang mencukupi untuk membayar uang pengganti sebagaimana dimaksud dalam ayat (1) huruf b, maka dipidana dengan pidana penjara yang lamanya tidak melebihi ancaman maksimum dari pidana pokoknya sesuai dengan ketentuan dalam Undang-undang ini dan lamanya pidana tersebut sudah ditentukan dalam putusan pengadilan. 
Berdasarkan ketentuan Pasal 18 Undang-Undang Pemberantasan Tindak Pidana Korupsi tersebut di atas, diperoleh beberapa pengertian. Pertama, di samping pidana pokok berupa pidana penjara atau pidana badan, berupa pidana mati, atau pidana penjara antara 1 (satu) tahun sampai dengan pidana penjara seumur hidup, sebagaimana diatur di dalam Pasal 2 sampai dengan Pasal 20, Undang-Undang Pemberantasan Tindak Pidana Korupsi, juga mengatur sanksi pidana tambahan yang dapat dijatuhkan kepada pelaku tindak pidana korupsi, yang terdiri dari 4 (empat) bentuk sanksi pidana, yakni perampasan aset, pembayaran uang pengganti, penutupan perusahaan, dan atau pencabutan hak pelaku tindak pidana korupsi.

Kedua, sanksi pidana tambahan baik berupa perampasan aset dan pembayaran uang pengganti, maupun penutupan perusahaan, dan atau pencabutan hak pelaku tindak pidana korupsi. memiliki hubungan yang sangat erat dengan jumlah kerugian negara. Artinya, jumlah kerugian negara yang terjadi akibat tindak pidana korupsi, merupakan dasar dalam menentukan seberapa banyak aset pelaku korupsi yang harus dirampas dan/atau disita, besarnya jumlah uang pengganti, skala penutupan perusahaan, dan seberapa jauh hak pelaku korupsi harus dicabut.

Ketiga, sanksi pidana tambahan berupa perampasan aset, dapat dilakukan baik dalam proses penyidikan, penuntutan, dan persidangan maupun setelah penjatuhan pidana, atau putusan pidana telah memiliki kekuatan hukum yang tetap. Perampasan aset sebelum penjatuhan pidana dilakukan terhadap barang bergerak yang berwujud atau yang tidak berwujud atau barang tidak bergerak yang digunakan untuk atau yang diperoleh dari tindak pidana korupsi, termasuk perusahaan dimana tindak pidana korupsi dilakukan. Sementara perampasan aset yang dilakukan setelah putusan berkekuatan hukum tetap, adalah terhadap penyitaan harta benda terpidana manakala terpidana tidak membayar uang pengganti, sebagaimana diatur di dalam pasal 18 ayat (1) huruf b Undang-Undang Pemberantasan Tindak Pidana Korupsi.

Apabila ditinjau dari sudut normatif, ketentuan tersebut di atas menimbulkan harapan yang cukup besar akan terjadinya pemberantasan tindak pidana korupsi secara sistemik dan komprehensif, yang tidak saja ditandai dengan dijatuhkannya hukuman terhadap pelaku tindak pidana atas perbuatannya mengkorupsi uang negara, tetapi juga harapan akan adanya penyelamatan uang negara melalui perampasan aset hasil korupsi untuk kemudian dapat dipergunakan sebesar-besarnya bagi kepentingan pembangunan nasional. 
Dengan demikian, dapat dikatakan bahwa secara normatif ketentuan Pasal 18 Undang-Undang Pemberantasan Tindak Pidana Korupsi, diharapkan dapat menjadi sarana hukum yang efektif untuk pemulihan kerugian negara akibat tindak pidana korupsi.

Selanjutnya bila dikaitkan dengan tujuan hukum, maka ketentuan Pasal 18 UndangUndang Pemberantasan Tindak Pidana Korupsi tersebut, tepat menjadi sarana bagi pencapaian tujuan ditegakkannya hukum yakni tercapainya asas kemanfaatan, dimana ketentuan tersebut akan sangat bermanfaat bagi penyelamatan uang negara demi kepentingan masyarakat dalam arti yang seluas-luasnya.

Namun demikian, dalam penerapannya ketentuan Pasal 18 Undang-Undang Pemberantasan Tindak Pidana Korupsi tersebut, seringkali menimbulkan pro dan kontra, terutama yang terkait dengan perampasan dan/atau penyitaan aset yang diduga atau dinyatakan sebagai harta yang diperoleh dari tindak pidana korupsi.

Dalam pandangan kalangan yang kontra, perampasan aset tersangka korupsi cenderung terkesan dilakukan tanpa aturan yang jelas, sedemikian sehingga manakala seseorang ditetapkan sebagai tersangka korupsi, maka seluruh asetnya disita begitu saja, tanpa memilah-milah terlebih dahulu harta atau aset yang mana saja, yang benar-benar diperoleh dari tindak pidana korupsi. Keadaan yang demikian, tentu saja sangat berpotensi menimbulkan kerugian, bahkan ketiadak-adilan dan ketidak-pastian hukum, terutama bagi tersangka pelaku tindak pidana korupsi atau keluarganya.

Untuk menguji kebenaran pendapat kalangan yang kontra tersebut, dilakukan analisis norma hukum perampasan aset korupsi dalam rangka pengembalian kerugian negara, sebagaimana dimaksud di dalam Pasal 18 Undang-Undang Pemberantasan Tindak Pidana Korupsi.

Analisis dilakukan untuk menemukan kelemahan-kelemahan dalam perumusan ketentuan Pasal 18 Undang-Undang Pemberantasan Tindak Pidana Korupsi, yang berpotensi menyebabkan ketentuan Pasal dimaksud tidak dapat diterapkan secara efektif. Hal itu penting dilakukan karena jika ketentuan Pasal tersebut tidak dapat dilakukan secara efektif, maka tidak ada pintu lain di dalam Undang-Undang Pemberantasan Tindak Pidana Korupsi, yang memungkinkan dipastikannya pengembalian kerugian negara akibat tindak pidana korupsi secara efektif.

Di dalam Pasal 18 Undang-Undang Pemberantasan Tindak Pidana Korupsi, terdapat beberapa ketentuan penting mengenai sanksi pidana perampasan aset korupsi. Ketentuan-ketentuan yang perlu mendapat perhatian tersebut adalah sebagai berikut: 
1. Kedudukan sanksi pidana perampasan aset korupsi sebagai sanksi pidana tambahan;

2. Perampasan aset dilakukan terhadap harta benda yang diperoleh tersangka/terdakwa dari tindak pidana korupsi;

3. Perampasan aset berkaitan erat dengan pengembalian kerugian negara;

4. Penyitaan terhadap harta benda terpidana dilakukan apabila terpidana tidak membayar uang pengganti. Harta tersebut disita dan dilelang untuk menutupi uang pengganti;

Untuk mendapatkan pembahasan yang bersifat komprehensif, maka pengkajian terhadap satu persatu dari masing-masing ketentuan penting di atas.

\section{Kedudukan Sanksi Pidana Perampasan Aset sebagai Pidana Tambahan}

Merujuk pada ketentuan Pasal 18 ayat (1) Undang-Undang Pemberan-tasan Tindak Pidana Korupsi, diperoleh beberapa kesimpulan. Pertama, kedudukan sanksi pidana perampasan aset dan 3 (tiga) bentuk sanksi pidana lainnya, merupakan pidana tambahan.

Kedua, sanksi pidana tambahan tersebut merupakan perluasan dari ketentuan sanksi pidana tambahan, yang sebelumnya telah menjadi bagian dari stelsel pidana Indonesia, sebagaimana diatur dalam Pasal 10 huruf b KUHP, yang pada pokoknya menggariskan bahwa pidana tambahan terdiri dari pencabutan hak-hak tertentu; perampasan barangbarang tertentu; pengumuman putusan hakim.

Apabila ketentuan Pasal 18 ayat (1) Undang-Undang Pemberantasan Tindak Pidana Korupsi, diperbandingkan dengan ketentuan Pasal 10 huruf b KUHP tentang pidana tambahan dan Pasal 39 KUHP mengenai ketentuan perampasan barang-barang yang diperoleh dari hasil kejahatan, maka disimpulkan bahwa 3 (tiga) bentuk sanksi pidana yang diatur di dalam Pasal 18 Undang-Undang Pemberantasan Tindak Pidana Korupsi, yakni perampasan barang bergerak yang berwujud atau yang tidak berwujud atau barang tidak bergerak yang digunakan untuk atau yang diperoleh dari tindak pidana korupsi, pembayaran uang pengganti, penutupan seluruh atau sebagian perusahaan dan pencabutan seluruh atau sebagian hak-hak tertentu, atau penghapusan seluruh atau sebagian keuntungan tertentu dari dari perusahaan dimaksud, sesungguhnya sudah termaktub di dalam Pasal 10 huruf $b$ dan Pasal 39 KUHP.

Pertanyaannya, apakah dengan penerapan saksi pidana perampasan aset yang kedudukannya sebagai pidana tambahan, dapat menjamin bahwa pada setiap terjadinya tindak pidana korupsi, akan terjadi pengembalian kerugian negara. 
Untuk memperoleh jawaban terhadap pertanyaan tersebut, pertama kali ditelusuri dari ketentuan di dalam Undang-Undang Pemberantasan Tindak Pidana Korupsi, yang terkait dengan ketentuan mengenai sanksi pidana perampasan aset.

Di dalam Pasal 17 Undang-Undang Pemberantasan Tindak Pidana Korupsi, dinyatakan bahwa "Selain dapat dijatuhi pidana sebagaimana dimaksud dalam Pasal 2, Pasal 3, Pasal 5 sampai dengan Pasal 14, terdakwa dapat dijatuhi pidana tambahan sebagaimana dimaksud dalam Pasal 18”.

Dengan menggunakan kata "dapat" di dalam frasa "terdakwa dapat dijatuhi pidana tambahan" sebagaimana bunyi Pasal 17 tersebut di atas, menjadi jelas bahwa terhadap seseorang yang berdasarkan fakta persidangan dan keyakinan Hakim, terbukti secara sah dan meyakinkan telah melakukan kejahatan korupsi, penerapan sanksi pidana perampasan aset, adalah sebuah pilihan atau bukanlah merupakan sesuatu hal yang wajib. Artinya, Majelis Hakim dapat menjatuhkan sanksi pidana perampasan aset, dapat pula tidak.

Ketentuan Pasal 17 Undang-Undang Pemberantasan Tindak Pidana Korupsi tersebut di atas, selaras dengan pendapat sejumlah ahli hukum. Menurut Roeslan Saleh, pidana tambahan dimaksudkan sebagai tambahan dari pidana pokok. Oleh karenanya pidana tambahan tersebut bersifat fakultatif, jadi boleh dijatuhkan boleh tidak. ${ }^{2}$

Sementara itu, Andi Hamzah berpendapat bahwa melihat namanya saja sudah nyata bahwa pidana tambahan hanya bersifat menambah pidana pokok yang dijatuhkan. Jadi tidaklah dapat berdiri sendiri, kecuali dalam hal-hal tertentu dalam perampasan barangbarang tertentu. Pidana tambahan ini bersifat fakultatif artinya dapat dijatuhkan tetapi tidaklah harus. $^{3}$

Mengenai perbedaan antara pidana pokok dengan pidana tambahan, Roeslan Saleh menjelaskan bahwa:

1. Pidana tambahan hanya dapat ditambahkan pada pidana pokok. Akan tetapi, inipun ada pengecualiannya. Perampasan barang-barang tertentu, misalnya dapat dilakukan terhadap anak yang diserahkan kepada pemerintahtetapi hanya mengenai barangbarang yang disita. Dalam hal ini ada pidana tambahan pada suatu tindakan (maatregel) dan bukanlah pidana pokok.

2. Pidana tambahan tidak mempunyai sifat keharusan. Jika Hakim yakin akan perbuatan pidana dan kesalahan terdakwa, maka terdakwa harus dijatuhi pidana pokok. Akan

\footnotetext{
${ }^{2}$ Periksa Roeslan Saleh, Stelsel Pidana Indonesia, Aksara baru, Jakarta 1983, hal. 10.

${ }^{3}$ Bandingkan Andi Hamzah, Op. Cit., , hal. 63.
} 
tetapi dalam menggunakan pidana tambahan, hakim merdeka ia boleh menjatuhkan pidana tambahan dan boleh pula tidak.

3. Mulai berlakunya pencabutan hak tidak dalam suatu tindakan eksekusi. Ayat penghabisan dari Pasal 38 KUHP menentukan bahwa pidana tambahan mulai berlaku pada hari putusan hakim dapat dijalankan. ${ }^{4}$

Pendapat lain dikemukakan oleh Utrecht. Ahli hukum pidana tersebut membedakan pidana pokok dan pidana tambahan pada tiga hal pokok, sebagai berikut :

1. Sesuai dengan kata tambahan di belakang kata hukuman itu, hukuman tambahan hanya dapat ditetapkan di samping satu hukuman utama. Apabila hakim tidak dapat menetapkan satu hukuman utama, maka dengan sendirinya ia tidak dapat menetapkan pula suatu hukuman tambahan;

2. Hukuman tambahan itu bersifat fakultatif. Apabila hakim yakin bahwa terdakwa bersalah, maka hakim itu harus menetapkan satu hukuman utama. Akan tetapi ia tidak wajib menetapkan satu hukuman tambahan, hakim itu bebas. Akan tetapi ada perkecualiannya, yaitu dalam beberapa hal Undang-Undang pidana menentukan perampasan barang itu secara imperatif. Jadi hakim harus menetapkan perampasan itu. Sebagai contoh dapat disebut pasal 250 bis, 261 dan 275 KUHP. ${ }^{5}$

Pendapat lain dikemukakan oleh Joko Prakoso bahwa pidana tambahan tidak bisa dijatuhkan secara tersendiri melainkan harus dijatuhkan bersama dengan pidana pokok. Penjatuhan pidana bersifat fakultatif, dalam arti bahwa hakim tidak selalu menjalankan pidana tambahan bagi setiap terdakwa yang diadili, melainkan terserah pada pertimbangannnya, apakah disamping menjatuhkan pidana tambahan atau tidak. ${ }^{6}$

Sedangkan Lamintang mengemukakan bahwa penjatuhan hukuman tambahan itu adalah fakultatif dalam beberapa hal yang merupakan pengecualian, dimana hukum itu dapat, akan tetapi tidak selalu harus dijatuhkan. Kewenangan untuk menjatuhkan hukuman tambahan tersebut digantungkan pada ketentuan yang disyaratkan di dalam satu atau lebih perbuatan-perbuatan yang dapat dihukum yang bersifat khusus. ${ }^{7}$

Dalam pada itu, Efi Laila Kholis mengemukakan perbedaan antara pidana tambahan dengan pidana pokok. Perbedaan tersebut adalah:

\footnotetext{
${ }^{4}$ Roeslan Saleh, Op. Cit..

${ }^{5}$ Bandingkan Utrecht, Hukum Pidana II, Tinta Mas, Surabaya, 1987, hal. 326-327

${ }^{6}$ Periksa Joko Prakoso, Hukum Penitensier Indonesia, Liberty Yogyakarta, 1988, hal. 69-70.

${ }^{7}$ Lamintang dan Simons, Kitab Pelaran Hukum Pidana, Pioner, Bandung, 1992, hal 13.
} 
1. Penjatuhan salah satu jenis pidana pokok adalah suatu keharusan atau imperatif. Sedangkan penjatuhan pidana tambahan bersifat fakultatif. Apabila dalam suatu persidangan terbukti bahwa terdakwa terbukti bersalah secara sah dan meyakinkan, maka hakim harus menjatuhkan salah satu pidana pokok sesuai jenis dan batas maksimum dari rumusan tindak pidana yang dilanggar tersebut. Sifat imperatif dapat dilihat pada rumusan tindak pidana, dimana terdapat dua kemungkinan yaitu diancamkan salah satu pidana pokok sehingga hakim mau tidak mau harus menjatuhkan pidana sesuai rumusan tersebut atau dapat juga tindak pidana yang diancam oleh dua atau lebih jenis pidana pokok sehingga hakim dapat memilih salah satu saja. Misalnya pada Pasal 2 ayat (2) Undang-undang Pemberantasan Tipikor memilih jenis pidana seumur hidup atau selama waktu tertentu antara empat tahun hingga dua puluh tahun.

Pada pidana tambahan hakim boleh menjatuhkan atau tidak pidana tambahan yang diancamkan terhadap si pelanggar. Misalnya, hakim dapat menjatuhkan salah satu pidana tambahan pada Pasal 18 Undang-Undang Pemberantasan Tipikor dalam hal terbukti melanggar Pasal 3 Undang-undang Pemberantasan Tipikor. Walaupun prinsipnya penjatuhan pidana tambahan adalah fakultatif tetapi terdapat pengecualian misalnya Pasal 250 bis KUHP;

2. Penjatuhan jenis pidana pokok harus bersamaan dengan pidana tambahan (beridir sendiri) sedangkan penjatuhan pidana tambahan harus bersamaan dengan pidana pokok.

3. Jenis pidana pokok yang dijatuhkan, bila telah mempunyai kekuatann hukum tetap diperlukan pelaksanaan (executie) sedangkan pidana tambahan tidak. Pada pidana pokok diperlukan eksekusi terhadap pencapaian pidana tersebut kecuali pidana pokok dengan bersyarat (Pasal 14 a KUHP) dan syarat yang ditentukan itu tidak dilanggar. Pada pidana tambahan misalnya pidana putusan hakim.

4. Pidana pokok tidak dapat dijatuhkan komulatif sedangkan pidana tambahan dapat. Akan tetapi dapat disimpangi pada beberapa UU termasuk Undang-undang Pemberantasan Tipikor. ${ }^{8}$

${ }^{8}$ Efi Laila Kholis, Pembayaran Uang Pengganti Dalam Perkara Korupsi, Solusi Publishing, Depok, 2010, hal. 14-15. 
Berdasarkan pendapat beberapa ahli hukum di atas, ditarik kesimpulan bahwa keberadaan sanksi pidana perampasan aset sebagai bagian dari pidana tambahan dalam stelsel pidana Indonesia, sesuai dengan namanya merupakan tambahan terhadap pidana pokok dan pengenaan pidana tersebut bersifat fakultatif, sehingga penerapannya atau akan dijatuhkan atau tidaknya pidana tambahan berupa pembayaran uang pengganti tersebut, diserahkan kepada pertimbangan Majelis Hakim. Dengan sifatnya yang tidak imperatif tersebut, tidak ada keharusan bagi penegak hukum untuk menerapkan ketentuan pidana perampasan aset terhadap pelaku tindak pidana korupsi.

Berdasarkan uraian di atas, disimpulkan bahwa ditinjau dari perspektif tujuan penegakan hukum paling hakiki terhadap tindak pidana korupsi, yakni memastikan terjadinya pemulihan kerugian negara, maka perumusan sanksi perampasan aset di dalam Undang-Undang Pemberantasan Tindak Pidana Korupsi, merupakan kebijakan hukum pidana yang bersifat sangat strategis.

Namun demikian, penempatan sanksi pidana perampasan aset sebagai pidana tambahan, justeru melemahkan penegakan hukum terhadap tindak pidana korupsi, karena sifatnya yang sekedar pilihan bukan perintah yang mau tidak mau harus diterapkan, sehingga tidak dapat menjamin bahwa pada setiap terjadinya tindak pidana korupsi, akan terjadi pengembalian kerugian negara.

Dengan demikian, terdapat norma hukum yang tidak jelas di dalam perumusan ketentuan Pasal 18 ayat (1) Undang-Undang Pemberantasan Tindak Pidana Korupsi, dimana ada norma tentang sanksi pidana perampasan aset, namun terbuka kesempatan untuk tidak memberlakukannya.

Demi mengantisipasi keadaan yang demikian, Jaksa Agung melakukan inisiasi dengan menerbitkan Surat Edaran Jaksa Agung Republik Indonesia Nomor SE 004/JA/8/1988 tanggal 5 Agustus 1988 tentang Pelaksanaan Pidana Tambahan Pembayaran Uang Pengganti (Pasal 34 huruf c Undang-Undang Nomor 3 tahun 1971).

Dalam Surat Edaran tersebut, salah satunya diatur tentang tahapan penuntutan, yang selengkapnya menggariskan bahwa:

Pada tahap penuntutan, Jaksa Penuntut Umum dalam tuntutan pidananya wajib meminta kepada Hakim agar menjatuhkan pidana tambahan berupa pembayaran uang pengganti (Pasal 34 huruf c Undang-Undang Nomor 3 tahun 1971), di samping pidana pokok, dan menjatuhkan putusan merampas barang-barang yang disita dalam tahap penyidikan. Nilai keseluruhan barang-barang yang dimohonkan untuk dirampas dan jumlah tuntutan 
pembayaran uang pengganti adalah sebanyak-banyaknya sama dengan harta benda yang diperoleh dari korupsi.

Untuk menindaklanjuti Surat Edaran Jaksa Agung tersebut, diterbitkan Petunjuk Jaksa Agung Bidang Tindak Pidana Khusus Nomor B-051/F/FPT.2/1/91 tanggal 17 Januari 1991, yang pada pokoknya mengatur bahwa dalam perkara tindak pidana korupsi dalam rangka menyelamatkan kembali keuangan negara, maka terhadap terdakwa selain dituntut dengan pidana pokok (pidana penjara dan denda), agar dituntut juga pidana tambahan membayar uang pengganti, kecuali bilamana seluruh keuangan negara akan dapat ditutupi kembali dengan tuntutan perampasan barang bukti yang dalam tingkat penyidikan telah disita ataupun dengan disetorkannya uang ke kas negara senilai jumlah kerugian negara.

Inisiasi Jaksa Agung, yang memerintahkan Jaksa Penuntut Umum untuk selalu menuntut penjatuhan pidana tambahan berupa pembayaran uang pengganti selain dari pidana pokok, pada satu sisi merupakan sebuah kebijakan yang tepat, yang mendukung penegakan hukum yang bersifat komprehensif terhadap pelaku tindak pidana korupsi.

Namun pada sisi lain, Surat Edaran tersebut tidak dapat dipakai sebagai dasar hukum yang kuat, karena hanya memiliki kekuatan hukum yang mengikat ke dalam institusi Kejaksaan saja. Selain itu, sekalipun setiap Jaksa Penuntut Umum telah memuat penjatuhan pidana uang pengganti, pada setiap tuntutannya terhadap pelaku tindak pidana korupsi, sesuai dengan perintah Jaksa Agung tersebut, hal itu tidak dapat menjamin atau memastikan bahwa Majelis Hakim akan memenuhi tuntutan tersebut. Dengan kata lain, tidak ada ketentuan lain, selain ketentuan Undang-Undang sajalah, yang mampu mempengaruhi putusan hakim, untuk menerapkan ketentuan mengenai perampasan aset. 3 . Aset yang Dirampas

Di dalam Pasal 18 ayat (1) huruf a, pada pokoknya ditegaskan bahwa harta atau aset yang dirampas adalah barang bergerak yang berwujud atau yang tidak berwujud atau barang tidak bergerak yang digunakan untuk atau yang diperoleh dari tindak pidana korupsi.

Namun demikian, tidak dijelaskan lebih lanjut apa yang dimaksud dengan "barang bergerak yang berwujud atau yang tidak berwujud atau barang tidak bergerak yang digunakan untuk atau yang diperoleh dari tindak pidana korupsi” tersebut. Di samping itu, 
juga tidak diatur cara menelusuri, menghitung harta dan atau membuktikan secara hukum bahwa harta tersebut benar-benar diperoleh dari hasil korupsi yang didakwakan,

Dengan demikian, norma perampasan aset korupsi tersebut merupakan norma yang bersifat tidak jelas (unclear norm), sehingga ketentuan Pasal 18 ayat (1) huruf a UndangUndang Pemberantasan Tindak Pidana Korupsi bersifat multi tafsir. Kekaburan norma perampasan aset korupsi tersebut, tentu saja menimbulkan kesulitan bagi penegak hukum di lapangan di dalam penerapannya. Di samping itu, penegak hukum pada masing-masing tingkatan pada akhirnya, memiliki perspektif atau cara pandang sendiri-sendiri dalam menafsirkan apa yang dimaksud dengan "harta yang diperoleh dari korupsi” tersebut.

Dapat dibayangkan, berbagai kerumitan yang harus dihadapi penegak hukum dalam menetapkan bahwa harta atau aset yang dimiliki oleh tersangka pelaku tindak pidana korupsi, diperoleh dari tindak pidana korupsi yang dilakukannya.

Majelis Hakim boleh jadi memerlukan keahlian khusus di luar kompetensinya sebagai Hakim untuk melakukan investigasi menyeluruh terhadap harta kekayaan pelaku korupsi. Hakim harus secara cermat dengan dukungan data dan informasi yang lengkap memilah-milah bagian mana dari keseluruhan harta terdakwa yang berasal dari tindak pidana korupsi yang didakwakan kepadanya, dan mana yang bukan.

Kerumitan yang lebih jauh akan dialami oleh Jaksa Penuntut Umum dan Majelis Hakim, manakala kemudian diketahui apabila harta tersebut telah berpindah tangan, atau telah dikonversi dalam bentuk aset yang nilainya fluktuatif atau aset-aset tersebut telah berada di luar wilayah hukum Indonesia. Hal itu sangat mungkin terjadi, mengingat bahwa rata-rata pelaku kejahatan korupsi adalah kalangan terdidik (white collar), yang dengan modus yang kompleks memindahkan asset-aset yang dimiliknya dari kejahatan korupsi, kepada orang lain dan atau ke negara lain.

Kekaburan norma mengenai harta yang diperoleh dari korupsi, di dalam Pasal 18 ayat (1) huruf a Undang-Undang Pemberantasan Tindak Pidana Korupsi tersebut, juga dirasakan oleh Kejaksaan Agung selaku institusi penyidik perkara tindak pidana korupsi. Hal itu terlihat dari diterbitkannya Surat Edaran Jaksa Agung melalui Jaksa Agung Muda Bidang Tindak Pidana Khusus Nomor B-051/F/FPT.2/1/91 tanggal 17 Januari 1991.

Surat Edaran Jaksa Agung tersebut secara garis besar memberi petunjuk kepada jajarannya bahwa jumlah pembayaran uang pengganti dalam ketentuan tersebut "sebanyakbanyaknya sama dengan harta benda yang diperoleh dari korupsi”, namun karena kesulitan untuk membuktikan harta kekayaan terdakwa yang diperoleh dari korupsi, maka ketentuan 
tersebut hendaknya ditafsirkan bahwa pembayaran uang pengganti adalah sebesar kerugian negara yang ditimbulkan oleh perbuatan terdakwa.

Akibat logis dari perspektif yang berbeda-beda dari penegak hukum akibat tidak diaturnya secara jelas dan tegas tentang perampasan aset korupsi tersebut, salah satunya adalah terjadinya perbedaan perlakuan terhadap pelaku tindak pidana korupsi. Di satu tempat bisa jadi seluruh harta pelaku tindak pidana korupsi dirampas atau disita, sementara di tempat lain tidak. Perbedaan perlakuan tersebut tidak saja akan merugikan atau menimbulkan ketidak-adilan dan ketidak-pastian hukum bagi pelaku tindak pidana korupsi, melainkan yang lebih penting lagi adalah bahwa kekaburan norma mengenai perampasan aset korupsi tersebut, pada gilirannya akan melemahkan penegakan hukum terhadap pelaku tindak pidana korupsi.

Dasar Perhitungan Kerugian Negara dan Instansi yang Berwenang Menghitung

\section{$\underline{\text { Kerugian Negara }}$}

Sebagaimana telah dikemukakan sebelumnya bahwa perampasan aset korupsi, sangat berkaitan dengan jumlah kerugian negara yang terjadi akibat sebuah tindak pidana korupsi. Artinya, secara normatif aset yang dirampas, sedapat mungkin harus mampu mengembalikan atau memulihkan kerugian yang diderita oleh negara akibat perbuatan korupsi.

Oleh karena itu, agar tujuan pemulihan kerugian negara dapat dicapai, tidak saja diperlukan norma perampasan aset yang jelas dan tegas, melainkan harus didukung pula oleh ketentuan yang secara jelas dan tegas mengatur segala suatu yang berkaitan dengan kerugian negara.

Terdapat 2 (dua) hal prinsipil terkait dengan kerugian negara, yakni tentang penetapan besarnya kerugian negara yang terjadi akibat tindak pidana korupsi, dan tentang pihak yang berwenang menetapkan besarnya krugian negara akibat tindak pidana korupsi.

Terkait dengan besarnya kerugian negara dan dasar perhitungan kerugian negara yang ditimbulkan dari perbuatan pidana korupsi, dapat dirujuk pada 2 (dua) Pasal di dalam Undang-Undang Pemberantasan Tindak Pidana Korupsi, yakni Pasal 18 ayat (1) huruf b, dan Penjelasan Pasal 32 ayat (1) .

Menurut ketentuan Pasal 18 ayat (1) huruf b Undang-Undang Pemberantasan Tindak Pidana Korupsi, besarnya uang pengganti adalah "sebanyak-banyaknya sama dengan harta benda yang diperoleh dari korupsi”. besarnya kerugian keuangan negara, sementara dalam Penjelasan Pasal 32 ayat (1), menjelaskan bahwa yang dimaksud dengan 
kerugian keuangan negara adalah kerugian negara yang sudah dapat dihitung jumlahnya berdasarkan hasil temuan instansi yang berwenang atau akuntan publik yang ditunjuk.

Perumusan ketentuan Pasal 18 ayat (1) huruf b dan Penjelasan Pasal 32 ayat (1) Undang-Undang Pemberantasan Tindak Pidana Korupsi tentang kerugian negara, cenderung bersifat multi tafsir dan sama sekali tidak menunjuk pada besarnya kerugian negara, yang harus dikembalikan oleh pelaku korupsi, melalui aset yang dimilikinya.

Kekaburan norma mengenai besarnya uang pengganti, di dalam Pasal 18 ayat (1) huruf b Undang-Undang Pemberantasan Tindak Pidana Korupsi tersebut, juga dirasakan oleh Kejaksaan Agung selaku institusi penyidik perkara tindak pidana korupsi. Hal itu terlihat dari diterbitkannya Surat Edaran Jaksa Agung melalui Jaksa Agung Muda Bidang Tindak Pidana Khusus Nomor B-051/F/FPT.2/1/91 tanggal 17 Januari 1991.

Surat Edaran Jaksa Agung tersebut secara garis besar memberi petunjuk kepada jajarannya bahwa jumlah pembayaran uang pengganti dalam ketentuan tersebut "sebanyakbanyaknya sama dengan harta benda yang diperoleh dari korupsi”, namun karena kesulitan untuk membuktikan harta kekayaan terdakwa yang diperoleh dari korupsi, maka ketentuan tersebut hendaknya ditafsirkan bahwa pembayaran uang pengganti adalah sebesar kerugian negara yang ditimbulkan oleh perbuatan terdakwa.

Efi Laila Kholis, menilai bahwa penafsiran yang dibuat oleh Jaksa Agung tersebut mengandung sisi positif dalam menetapkan besaran uang pengganti yakni sama dengan jumlah kerugian negara yang ditimbulkan. Sisi positif dari penetapan yang demikian adalah menghindari kerepotan hakim dalam memilah dan menghitung aset terpidana karena besarnya sudah jelas serta memudahkan pengembalian uang negara. ${ }^{9}$

Pendapat Efi Laila Kholis tersebut, pada satu sisi mengandung kebenaran. Dengan ditetapkannya besaran tertentu terhadap kerugian negara yang ditimbulkan, akan memudahkan proses penjatuhan pidana pembaran uang pengganti.

Namun demikian, pada sisi lain Surat Edaran Jaksa Agung tentang jumlah uang pengganti tersebut, sama sekali belum mampu menjawab hal substantif tentang kerugian negara, karena Surat Edaran dimaksud tidak menjelaskan sama sekali berapa besar kerugian negara yang sesungguhnya terjadi, akibat suatu tindak pidana korupsi.

Dengan demikian, disimpulkan bahwa ditinjau dari penentuan besarnya kerugian negara akibat tindak pidana korupsi, Undang-Undang Pemberantasan Tindak Pidana

\footnotetext{
${ }^{9}$ Periksa Evi Laila Kholis, Op. Cit., hal. 19.
} 
Korupsi tidak mengatur secara jelas dan tegas, tentang apa yang dimaksud dengan kerugian negara, dan bagaimana menetapkan besarnya kerugian keuangan yang sesungguhnya dialami negara dari setiap adanya tindak pidana korupsi.

Persoalan prinsipil kedua terkait dengan kerugian negara akibat tindak pidana korupsi, adalah ketentuan yang mengatur mengenai instansi yang diberi wewenang oleh Undang-Undang, untuk menghitung dan menetapkan besarnya kerugian negara.

Terkait dengan kewenangan penentuan besarnya kerugian negara, dapat dirujuk ketentuan Pasal 23 E Undang-Undang Dasar Republik Indonesia Tahun 1945 (UndangUndang Dasar 1945), Pasal 8, dan Pasal 10 Undang-Undang Nomor 15 Tahun 2006 Tentang Badan Pemeriksaan Keuangan (Undang-Undang Badan Pemeriksaan Keuangan).

Pasal 23 E Undang-Undang Dasar 1945 hasil amandemen ketiga yang disahkan tanggal 10 November 2001, mengamanatkan bahwa:

(1) Untuk memeriksa pengelolaan dan tanggungjawab tentang keuangan negara diadakan satu Badan Pemeriksaan Keuangan yang bebas dan mandiri.

(2) Hasil pemeriksaan keuangan negara diserahkan kepada Dewan Perwakilan Rakyat, Dewan Perwakilan Daerah, dan Dewan Perwakilan Rakyat Daerah, sesuai dengan kewenangannya.

(3) Hasil pemeriksaan tersebut ditindak-lanjuti oleh lembaga perwakilan dan/atau badan sesuai dengan undang-undang.

Berdasarkan ketentuan Pasal 23 E Undang-Undang Dasar 1945 tersebut di atas, secara nyata terlihat bahwa badan yang secara konstitusional diberi kewenangan melakukan pemeriksaan pengelolaan keuangan negara, adalah Badan Pemeriksaan Keuangan (BPK). Hasil pemeriksaan BPK pulalah yang kemudian ditindak-lanjuti oleh lembaga perwakilan dan/atau badan sesuai dengan Undang-Undang.

Selanjutnya, di dalam Pasal 8 Undang-Undang Badan Pemeriksaan Keuangan, digariskan sebagai berikut:

1. Untuk keperluan tindak lanjut hasil pemeriksaan sebagaimana dimaksud dalam Pasal 7 ayat (1), BPK menyerahkan pula hasil pemeriksaan secara tertulis kepada Presiden, Gubernur, Bupati/Walikota sesuai dengan kewenangannya.

2. Tindak lanjut hasil pemeriksaan sebagaimana dimaksud pada ayat (1) diberitahukan secara tertulis oleh Presiden, Gubernur, Bupati/Walikota kepada BPK. 
3. Apabila dalam pemeriksaan ditemukan unsur pidana, BPK melaporkan hal tersebut kepada instansi yang berwenang sesuai dengan ketentuan peraturan perundang undangan paling lama 1 (satu) bulan sejak diketahui adanya unsur pidana tersebut.

4. Laporan BPK sebagaimana dimaksud pada ayat (3) dijadikan dasar penyidikan oleh pejabat penyidik yang berwenang sesuai dengan peraturan perundang-undangan.

5. BPK memantau pelaksanaan tindak lanjut hasil pemeriksaan yang dilakukan oleh pejabat sebagaimana dimaksud pada ayat (1), dan hasilnya diberitahukan secara tertulis kepada DPR, DPD, dan DPRD, serta Pemerintah.

Kemudian di dalam Pasal 10, dirumuskan wewenang BPK sebagai berikut:

(1) BPK menilai dan/atau menetapkan jumlah kerugian negara yang diakibatkan oleh perbuatan melawan hukum baik sengaja maupun lalai yang dilakukan oleh bendahara, pengelola BUMN/BUMD, dan lembaga atau badan lain yang menyelenggarakan pengelolaan keuangan negara.

(2) Penilaian kerugian keuangan negara dan/atau penetapan pihak yang berkewajiban membayar ganti kerugian sebagaimana dimaksud pada ayat (1) ditetapkan dengan keputusan BPK.

(3) Untuk menjamin pelaksanaan pembayaran ganti kerugian, BPK berwenang memantau:

a. penyelesaian ganti kerugian negara/daerah yang ditetapkan oleh Pemerintah terhadap pegawai negeri bukan bendahara dan pejabat lain;

b. pelaksanaan pengenaan ganti kerugian negara/daerah kepada bendahara, pengelola BUMN/BUMD, dan lembaga atau badan lain yang mengelola keuangan negara yang telah ditetapkan oleh BPK; dan

c. pelaksanaan pengenaan ganti kerugian negara/daerah yang ditetapkan berdasarkan putusan pengadilan yang telah mempunyai kekuatan hukum tetap.

(4) Hasil pemantauan sebagaimana dimaksud pada ayat (3) diberitahukan secara tertulis kepada DPR, DPD, dan DPRD sesuai dengan kewenangannya.

Berdasarkan ketentuan Pasal 8 dan Pasal 10 Undang-Undang Badan Pemeriksa Keuangan tersebut di atas, jelas pula bahwa instansi yang diberikan kewenangan untuk melakukan audit investigatif, dan melaporkan hasil audit investigatif yang mengandung unsur pidana, kepada instansi yang berwenang untuk kemudian dijadikan dasar penyidikan adalah BPK. 
Namun dalam praktiknya, audit investigatif terhadap dugaan adanya tindak pidana korupsi dan perhitungan kerugian negara, juga dilakukan oleh Badan Pengawas Keuangan Pembangunan (BPKP). BPKP merupakan salah satu lembaga pemerintah yang bekerja berdasarkan Keputusan Presiden Nomor 103 Tahun 2001 Tentang Kedudukan, Tugas, Fungsi, Kewenangan, Susunan Organisasi, dan Tata Kerja Lembaga Pemerintah Non Departemen Presiden Republik Indonesia, yang mengatur bahwa BPKP mempunyai wewenang melaksanakan tugas pemerintah di bidang pengawasan keuangan dan pembangunan sesuai dengan ketentuan peraturan perundang-undangan yang berlaku. Selain itu tugas BPKP adalah melakukan pengawasan intern melalui audit investigatif. Yang dimaksud audit investigatif adalah merupakan bagian dari pengawasan intern pemerintah berdasarkan Peraturan Pemerintah No. 60 Tahun 2008 Tentang Sistem Pengendalian Intern Pemerintah (SPIP).

Terkait dengan kewenangan BPKP melakukan audit investigasi Duke Arie, menjelaskan bahwa:

Pada dasarnya semangat audit investigatif oleh BPKP berdasarkan persfektif undangundang di atas bukan merupakan audit yang hasilnya dapat dijadikan dasar untuk mengungkap kasus korupsi tetapi lebih merupakan tindakan pengawasan (bukan pemeriksaan) internal pemerintahan yang bersifat preventif, yaitu berupa laporan pertanggungjawaban kepada presiden. Artinya BPKP memperoleh kewenangannya melalui delegasi Presiden sebagai sistem internal pengendali pemerintah. BPKP sebagai pengawas internal memberikan peringatan dini sebelum adanya temuan BPK. Sehingga seharusnya BPKP kalaupun sampai pada tindak pidana korupsi sebenarnya bukan merupakan upaya terakhir (ultimum remedium), setelah melalui proses tuntutan ganti rugi ataupun proses administratif internal lainnya. ${ }^{10}$

Tidak adanya kejelasan tentang instansi yang benar-benar diberi wewenang untuk menetapkan kerugian negara tersebut, pada praktiknya di lapangan, kerap kali menjadi silang sengketa yang sangat berpotensi menimbulkan ketidak-pastian hukum, yang pada akhirnya melemahkan penegakan hukum terhadap tindak pidana korupsi.

Terlepas dari kaburnya norma yang mengatur tentang instansi yang diberi wewenang melakukan audit investigasi terhadap kerugian negara akibat tindak pidana korupsi, Undang-Undang Pemberantasan Tindak Pidana Korupsi, juga memuat kekaburan

${ }^{10}$ Duke Arie, Kewenangan Audit Investigatif BPKP dan Korupsi, http://gorontalomaju.com/opini/artikel- lainnya/kewenangan-audit-investigatif-bpkp-dan- korupsi..html, diakses pada tanggal 20 Juli 2010. 
norma mengenai cara atau standar penetapan besarnya kerugian yang benar-benar dialami oleh negara, akibat suatu tindak pidana korupsi.

Ketiadaan kejelasan dan ketegaan pengertian dari kerugian negara, instansi yang berwenang menetapkan kerugian negara dan tidak adanya standar perhitungan kerugian negara yang baku, seringkali menyebabkan angka-angka besaran kerugian negara, yang berbeda antara satu instansi dengan instansi lainnya, sebutlah antara BPK dengan BPKP.

Karena sudut pandang yang berbeda dalam penilaian mengenai kerugian negara, kedua instansi tersebut tidak saja seringkali menerbitkan angka kerugian negara yang berbeda, bahkan dalam kasus-kasus tertentu, BPK dan BPKP memiliki pandangan yang secara ektrim bertentangan. Satu instansi menganggap ada kerugian negara, sementara instansi lainnya, dengan standar perhitungannya sendiri, justeru berkesimpulan bahwa sama sekali tidak ada kerugian negara yang ditimbulkan.

Ketiadaan cara penetapan besarnya kerugian negara yang diatur di dalam UndangUndang Pemberantasan Tindak Pidana Korupsi, tidak saja terjadi pada tahap penyidikan dan penuntutan, melainkan juga membawa dampak pada perbedaan cara pandang dari Majelis Hakim, baik pada pengadilan tingkat pertama, hakim banding, hakim kasasi, maupun hakim peninjauan kembali, dalam menjatuhkan putusan terhadap terdakwa tindak pidana korupsi.

Dengan demikian, terlihat dengan jelas bahwa kekaburan norma mengenai instansi yang diberi wewenang untuk melakukan audit investigasi dan penghitungan kerugian negara, dan cara atau standar penetapan besarnya kerugian negara, telah menimbulkan kerancuan hukum, sedemikian sehingga berpotensi menimbulkan ketidak-adilan, ketidakpastian hukum, yang pada gilirannya akan melemahkan penegakan hukum terhadap tindak pidana korupsi.

\section{Waktu Penyitaan Harta Benda Terpidana Korupsi}

Sebagaimana telah disinggung di muka bahwa terhadap terpidana yang putusannya telah memiliki kekuatan hukum tetap, tidak mampu membayar uang pengganti, maka kepadanya diberlakukan ketentuan Pasal 18 ayat (2) Undang-Undang Pemberantasan Tindak Pidana Korupsi, yang pada pokoknya mengatur bahwa "Jika terpidana tidak membayar uang pengganti, paling lama dalam waktu 1 (satu) bulan sesudah putusan pengadilan yang telah memperoleh kekuatan hukum tetap, maka harta bendanya dapat disita oleh jaksa dan dilelang untuk menutupi uang pengganti tersebut”. 
Berdasarkan ketentuan Pasal 18 ayat (2) Undang-Undang Pemberan-tasan Tindak Pidana Korupsi tersebut, disimpulkan bahwa penyitaan terhadap harta benda milik terpidana korupsi yang tidak mampu membayar uang pengganti, baru bisa dilakukan paling cepat dalam waktu 1 (satu) bulan sesudah putusan pengadilan terhadap si terpidana itu, memperoleh kekuatan hukum tetap.

Setidaknya terdapat 2 (dua) hal yang harus diperhatikan, terkait dengan waktu penyitaan dan pelelangan harta benda milik terpidana korupsi. Pertama. diperlukan waktu yang relatif lama untuk suatu putusan dinyatakan memiliki kekuatan hukum tetap, apabila terhadap putusan pengadilan tingkat pertama, terdakwa dan atau Jaksa Penuntut Umum mengajukan upaya hukum banding dan kasasi.

Kedua, karakteristik umum pelaku tindak pidana korupsi, adalah kalangan terdidik yang menguasai cara-cara yang canggih, dalam pemindahan asset-aset yang diperolehnya dari kejahatan korupsi, kepada orang lain dan atau ke negara lain, atau mengkonversinya ke dalam asset yang bernilai fluktuatif, seperti saham dan obligasi, atau menginvestasikannya ke dalam berbagai jaringan bisnis dengan nama orang lain.

Berdasarkan pertimbangan terhadap 2 (dua) hal di atas, maka disimpulkan bahwa penyitaan harta benda terpidana korupsi setelah 1 (satu) bulan putusannnya berkekuatan hukum tetap, jelas merupakan upaya yang sangat terlambat. Dengan kata lain, pada saat akan dilakukan penyitaan, diyakini sebagian terpidana korupsi, sudah tidak lagi memiliki aset yang memadai untuk disita dan dilelang.

Selanjutnya, kalaupun masih ada harta terpidana korupsi yang dapat disita, maka masih dibutuhkan waktu yang relatif lama untuk melakukan pelelangan terhadap harta sitaan hasil korupsi tersebut, sesuai ketentuan peraturan per undang-undangan.

Ketentuan mengenai prosedur pelelangan harta sitaan hasil tindak pidana korupsi, antara lain diatur di dalam Pasal 9 Peraturan Menteri Keuangan Nomor 03/PMK.06/2010 Tentang Pengelolaan Barang Milik Negara Yang Berasal Dari Barang Rampasan Negara Dan Barang Gratifikasi, yang selengkapnya mengatur bahwa:

Pasal 9

Dalam pengurusan Barang Rampasan Negara sebagaimana dimaksud dalam Pasal 8, Kejaksaan memiliki wewenang dan tanggung jawab meliputi:

a. melakukan Penatausahaan;

b. menguasakan kepada Kantor Pelayanan untuk melakukan penjualan secara lelang Barang Rampasan Negara dalam waktu 3 (tiga) bulan, dan dapat diperpanjang untuk 
paling lama 1 (satu) bulan, yang hasilnya disetorkan ke kas negara sebagai Penerimaan Negara Bukan Pajak berupa penerimaan umum pada Kejaksaan.

c. melakukan pengamanan administrasi, pengamanan fisik dan pengamanan hukum terhadap Barang Rampasan Negara yang berada dalam penguasaannya;

d. mengajukan usul penetapan status penggunaan, pemanfaatan, pemindahtanganan, pemusnahan dan penghapusan kepada Menteri atau kepada pejabat yang menerima pelimpahan wewenang Menteri sesuai dengan batas kewenangan; dan e. melaksanakan kewenangan lain sesuai ketentuan peraturan perundang-undangan.

Berangkat dari uraian di atas, disimpulkan bahwa Meskipun ada ketentuan Pasal 39 KUHAP, mengenai ketentuan perampasan barang-barang yang diperoleh dari hasil kejahatan, yang memungkinkan Penyidik untuk melakukan penyitaan secara dini pada tahap penyidikan, perumusan norma yang mengatur mengenai penyitaan dan pelelangan harta benda terpidana korupsi, di dalam Pasal 18 ayat (2) Undang-Undang Pemberantasan Tindak Pidana Korupsi, cenderung bukannya memperkuat, melainkan malah melemahkan upaya untuk semaksimal mungkin menutupi kerugian negara, dari penyitaan terhadap harta benda terpidana korupsi.

Dengan demikian, terhadap ketentuan Pasal 18 ayat (2) Undang-Undang Pemberantasan Tindak Pidana Korupsi, disimpulkan bahwa norma penyitaan harta benda untuk menutupi uang pengganti yang tidak dibayar oleh terpidana korupsi, merupakan norma yang kabur. Kekaburan norma mana yang terjadi karena keberadaan norma tersebut, justeru menjadi faktor penghambat terjadinya pengekan hukum yang tegas berupa pengembalian kerugian negara secara optimal dari pelaku tindak pidana korupsi.

Mengacu pada uraian di atas, ditarik kesimpulan akhir pada bagian ini bahwa norma hukum tentang perampasan aset korupsi dalam upaya pemberantasan tindak pidana korupsi menurut hukum pidana Indonesia, diatur di dalam Pasal 18 Undang-Undang Pemberantasan Tindak Pidana Korupsi. Norma hukum perampasan aset korupsi merupakan upaya hukum yang paling bersifat strategis, karena apabila ketentuan mengenai sanksi pidana perampasan aset korupsi dapat diterapkan secara efektif, maka upaya pengembalian kerugian negara akibat tindak pidana korupsi, akan mencapai hasilnya secara optimal. Namun demikian, secara normatif, ketentuan mengenai sanksi pidana perampasan aset korupsi di dalam Undang-Undang Pemberantasan Tindak Pidana Korupsi, sulit untuk dapat diterapkan secara efektif, karena terdapat sejumlah kelemahan yang 
menjadi faktor penghambat penerapannya. Kelemahan dimaksud adalah kedudukan dari pidana perampasan aset korupsi, sebagai sekedar pidana tambahan yang penerapannya bersifat fakultatif, ketiadaan ketentuan yang jelas dan tegas tentang cara pembuktian aset hasil korupsi, instansi yang berwenang menetapkan kerugian negara dan tidak adanya cara atau standar penetapan besarnya kerugian negara, dan terlalu lamanya waktu yang ditetapkan Undang-undang untuk melakukan penyitaan terhadap harta benda terpidana. Kekaburan norma dalam perumusan ketentuan Pasal 18 Undang-Undang Pemberantasan Tindak Pidana Korupsi, telah secara nyata menghambat dan atau melemahkan upaya pengembalian kerugian negara, yang menjadi salah satu tujuan utama dari penegakan hukum terhadap tindak pidana korupsi.

5. Faktor yang Sebaiknya Diterapkan Agar Perampasan Aset Korupsi Dapat Menjamin Pengembalian Kerugian Negara Akibat Tindak Pidana Korupsi

Berangkat dari kesimpulan pada bagian sebelumnya, bahwa penegakan hukum terhadap tindak pidana korupsi, terutama pada aspek pengembalian kerugian negara, tidak dapat dilaksanakan secara efektif karena adanya kelemahan dalam perumusan ketentuan mengenai sanksi pidana perampasan aset korupsi, di dalam Pasal 18 Undang-Undang Pemberantasan Tindak Pidana Korupsi.

Untuk memudahkan pemahaman, kelemahan perumusan ketentuan Pasal 18 Undang-Undang Pemberantasan Tindak Pidana Korupsi, ditabulasikan sebagai berikut:

\begin{tabular}{|c|c|c|}
\hline No & Pasal & Kelemahan Perumusan \\
\hline 1. & $\begin{array}{l}\text { Pasal } 18 \text { ayat (1) huruf b: } \\
\text { Selain pidana tambahan seba-gaimana } \\
\text { dimaksud dalam Kitab Undang-Undang } \\
\text { Hukum Pidana, sebagai pidana tambahan } \\
\text { adalah: } \\
\text { Perampasan barang bergerak yang } \\
\text { berwujud atau yang tidak berwujud atau } \\
\text { barang tidak bergerak yang digunakan } \\
\text { untuk atau yang diperoleh dari tindak } \\
\text { pidana korupsi, termasuk perusahaan milik } \\
\text { terpidana dimana tindak pidana korupsi }\end{array}$ & $\begin{array}{l}\text { Kedudukan sanksi pidana } \\
\text { perampasan aset korupsi adalah } \\
\text { sanksi pidana tambahan, yang } \\
\text { penerapannya bersifat fakultatif. } \\
\text { Tidak ada keharusan bagi Majelis } \\
\text { Hakim untuk menerapkan sebuah } \\
\text { sanksi pidana tambahan. }\end{array}$ \\
\hline
\end{tabular}




\begin{tabular}{|c|c|c|}
\hline & $\begin{array}{l}\text { dilakukan, begitu pula dari barang yang } \\
\text { mengantikan barang-barang tersebut }\end{array}$ & \\
\hline 2. & Pasal 18 ayat (1) huruf a & $\begin{array}{l}\text { 1. Frasa "yang diperoleh dari } \\
\text { tindak pidana korupsi", } \\
\text { merupakan norma hukum yang } \\
\text { kabur karena tidak menjelaskan } \\
\text { cara untuk menentukan harta } \\
\text { yang diperoleh dari korupsi; } \\
\text { 2. Tidak ada standar atau cara } \\
\text { perhitungan kerugian negara } \\
\text { akibat sebuah tindak pidana } \\
\text { korupsi, yang baku; } \\
\text { 3. Tidak dijelaskan instansi mana } \\
\text { yang berwenang menetapkan } \\
\text { jumlah kerugian negara. } \\
\text { 4. Undang-Undang lain yang } \\
\text { terkait telah mengatur dengan } \\
\text { tegas bahwa BPK yang } \\
\text { berwenang menetapkan } \\
\text { kerugian negara } \\
\text { menyerahkan indikasi pidana } \\
\text { kepada penyidik }\end{array}$ \\
\hline 3. & $\begin{array}{l}\text { Pasal } 18 \text { ayat (2): } \\
\text { Jika terpidana tidak membayar uang } \\
\text { pengganti sebagaimana dimaksud dalam } \\
\text { ayat (1) huruf b paling lama dalam waktu } 1 \\
\text { (satu) bulan sesudah putusan pengadilan } \\
\text { yang telah memperoleh kekuatan hukum } \\
\text { tetap, maka harta bendanya dapat disita } \\
\text { oleh jaksa dan dilelang untuk menutupi } \\
\text { uang pengganti tersebut. }\end{array}$ & $\begin{array}{l}\text { 1. Penyitaan harta benda terpidana } \\
\text { korupsi setelah } 1 \text { (satu) bulan } \\
\text { putusannnya berkekuatan } \\
\text { hukum tetap, merupakan upaya } \\
\text { yang sangat terlambat. Dengan } \\
\text { kata lain, pada saat akan } \\
\text { dilakukan penyitaan, diyakini } \\
\text { sebagian terpidana korupsi, } \\
\text { sudah tidak lagi memiliki aset } \\
\text { yang memadai untuk disita dan } \\
\text { dilelang, karena waktu yang }\end{array}$ \\
\hline
\end{tabular}




\begin{tabular}{|l|l|}
\hline \multicolumn{1}{|c|}{ dibutuhkan sampai sebuah } \\
putusan memiliki kekuatan \\
hukum tetap, dan karakteristik \\
pelaku kejahatan korupsi \\
sebagai white collar, yang \\
mudah mengalihkan assetnya \\
kepada orang lain atau ke negara \\
lain \\
2. Prosedur pelelangan menurut \\
Peraturan Menteri Keuangan, \\
membutuhkan waktu yang \\
relatif lama
\end{tabular}

Berdasarkan tabulasi kelemahan perumusan Pasal 18 Undang-Undang Pemberantasan tindak Pidana Korupsi di atas, dapat direkonstruksi konsepsi kebijakan hukum pidana yang sebaiknya dinormakan, agar ketentuan sanksi pidana perampasan aset korupsi dapat diterapkan secara efektif, sedemikian sehingga benar-benar mampu menjamin bahwa pada setiap tindak pidana korupsi, akan terjadi pengembalian kerugian negara.

Konsepsi kebijakan hukum pidana yang diajukan adalah sebagai berikut:

1. Kedudukan Sanksi Pidana Perampasan Aset Korupsi

Agar penegakan hukum terhadap tindak pidana korupsi, benar-benar dapat diwujudkan dan mampu mencapai tujuannya yang hakiki, yakni pengembalian kerugian negara, maka kedudukan sanksi pidana perampasan aset korupsi, harus diperkuat dari sanksi pidana tambahan yang bersifat fakultatif, menjadi bagian dari pidana pokok, yang bersifat imperatif atau harus diterapkan oleh Majelis Hakim terhadap pelaku tindak pidana korupsi.

Perubahan kedudukan pidana perampasan aset korupsimenjadi pidana pokok tersebut akan memberikan kepastian hukum bahwa dalam setiap terjadinya tindak pidana korupsi, terdakwa pasti dijatuhi pidana perampasan aset korupsi. Dengan demikian, akan terjadi pula kepastian hukum terhadap pengembalian kerugian negara akibat suatu perbuatan pidana korupsi. 
2. Dasar Penentuan Besarnya Kerugian Negara dan Instansi yang Ber-wenang Menentukannya

Penguatan hukum terhadap kedudukan pidana perampasan aset korupsi dari pidana tambahan menjadi pidana pokok, diyakini tidak akan mencapai hasil yang optimal, manakala tidak ada kepastian hukum mengenai besaran jumlah kerugian negara yang ditimbulkan dan instansi yang berwenang menetapkannya.

Oleh karena itu, konsepsi yang diajukan antara lain adalah bahwa Undang-Undang Pemberantasan Tindak Pidana Korupsi harus memuat ketentuan yang menyebut secara jelas dan tegas, bagaimana cara atau standar menentukan besaran kerugian negara dari sebuah perkara korupsi, dan instansi mana yang diberi wewenang oleh Undang-Undang untuk menentukan besarnya kerugian negara dimaksud.

Dengan pengaturan mengenai standar penghitungan besarnya kerugian negara dan penetapan otoritas yang diberi wewenang melakukan audit investigasai dan penghitungan kerugian negara tersebut, diyakini akan mampu memenuhi asas keadilan dan kepastian hukum, baik bagi negara sebagai korban langsung dari tindak pidana korupsi, maupun bagi pelaku kejahatan korupsi itu sendiri.

\section{Waktu Penyitaan Harta Benda Terpidana Korupsi}

Mengantisipasi berpindah-tangannya, berganti-bentuknya atau mengalirnya harta benda yang dimiliki oleh pelaku tindak pidana korupsi ke luar negeri, akibat waktu penyitaan yang demikian terlambat sebagaimana diatur di dalam Pasal 18 ayat (2) UndangUndang Pemberantasan Tindak Pidana Korupsi, maka haruslah diatur secara jelas bahwa agar kerugian negara yang timbul akibat tindak pidana korupsi dapat benar-benar dikembalikan, maka penyitaan terhadap harta benda yang diduga diperoleh dari kejahatan korupsi, harus dilakukan secara dini, yakni pada tahap penyidikan.

Merujuk pada uraian di atas, disimpulkan bahwa agar ketentuan yang mengatur mengenai sanksi pidana perampasan aset korupsi dapat diterapkan secara efektif, sedemikian sehingga benar-benar mampu menjamin bahwa pada setiap tindak pidana korupsi, akan terjadi pengembalian kerugian negara secara optimal, maka kebijakan hukum pidana yang sebaiknya dinormakan di dalam Undang-Undang Pemberantasan Tindak Pidana Korupsi, adalah norma hukum yang mengatur secara jelas dan tegas, tentang kedudukan pidana perampasan aset korupsisebagai bagian dari pidana pokok, standar atau perhitungan kerugian negara dan instansi yang berwenang menetapkan kerugian negara 
akibat tindak pidana korupsi, dan penyitaan harta benda milik tersangka korupsi secara dini.

\section{E. Kesimpulan}

Berdasarkan uraian diatas, maka dapat diambil beberapa kesimpulan sebagai berikut :

1. Pengaturan tentang perampasan aset korupsi dalam upaya pemberantasan tindak pidana korupsi menurut hukum pidana Indonesia, diatur di dalam Pasal 18 Undang-Undang Pemberantasan Tindak Pidana Korupsi. Norma hukum perampasan aset korupsi merupakan upaya hukum yang paling bersifat strategis, karena apabila ketentuan mengenai sanksi pidana perampasan aset korupsi dapat diterapkan secara efektif, maka upaya pengembalian kerugian negara akibat tindak pidana korupsi, akan mencapai hasilnya secara optimal. Namun demikian, ketentuan mengenai sanksi pidana perampasan aset korupsi tersebut, sulit untuk dapat diterapkan secara efektif, karena terdapat sejumlah kelemahan yang menjadi faktor penghambat penerapannya. Kelemahan dimaksud adalah kedudukan dari pidana perampasan aset korupsi, sebagai sekedar pidana tambahan yang penerapannya bersifat fakultatif, ketiadaan ketentuan yang jelas dan tegas tentang cara pembuktian aset hasil korupsi, instansi yang berwenang menetapkan kerugian negara, dan tidak adanya cara atau standar penetapan besarnya kerugian negara, dan terlalu lamanya waktu yang ditetapkan Undang-undang untuk melakukan penyitaan terhadap harta benda terpidana. Kekaburan norma dalam perumusan ketentuan Pasal 18 Undang-Undang Pemberantasan Tindak Pidana Korupsi, telah secara nyata menghambat dan atau melemahkan upaya pengembalian kerugian negara, yang menjadi salah satu tujuan utama dari penegakan hukum terhadap tindak pidana korupsi.

2. Kebijakan hukum pidana yang sebaiknya dinormakan di dalam Undang-Undang Pemberantasan Tindak Pidana Korupsi, adalah norma hukum yang mengatur secara jelas dan tegas, tentang kedudukan pidana perampasan aset korupsi sebagai bagian dari pidana pokok, standar atau perhitungan kerugian negara dan instansi yang berwenang menetapkan kerugian negara akibat tindak pidana korupsi, dan percepatan penyitaan harta benda milik tersangka korupsi.

\section{F. Rekomendasi}


1. Agar norma hukum dalam Pasal 18 Undang-Undang Pemberantasan Tindak Pidana Korupsi, dapat memperkuat penegakan hukum yang efektif terhadap tindak pidana korupsi, terutama dalam pengembalian kerugian negara, maka norma yang kabur di dalam Pasal 18 Undang-Undang Pemberantasan Tindak Pidana Korupsi, harus diperjelas dan dipertegas sedemikian sehingga tidak terbuka peluang untuk ditafsirkan menurut cara pandang masing-masing penegak hukum di lapangan;

2. Agar fenomena korupsi yang kian marak dapat diberantas secara sistemik melalui kebijakan hukum pidana, maka harus segera dilakukan perubahan terhadap perumusan Undang-Undang Pemberantasan Tindak Pidana Korupsi, sedemikian sehingga memuat ketentuan yang jelas dan tegas, setidaknya pada ketentuan yang mengatur mengenai sanksi pidana perampasan aset korupsi, sesuai dengan konsepsi pembaharuan hukum pidana yang diajukan di dalam penelitian ini.

\section{G. Daftar Pustaka}

Mardjono Reksodiputro, Kriminologi dan Sistem Peradilan Pidana, Kumpulan Karangan Buku Kedua, Pusat Pelayanan Keadulan dan Pengabdian Hukum (d/h Lembaga Kriminologi), Universitas Indonesia, Jakarta, 2007

Bandingkan Muladi dan Barda Nawawi Arief, Teori-teori dan Kebijakan Pidana, Cet. Ketiga, Alumni, Bandung, 2005

Sudarto, Hukum dan Hukum Pidana, Alumni, Bandung, 1981

Periksa Roeslan Saleh, Stelsel Pidana Indonesia, Aksara baru, Jakarta 1983. Utrecht, Hukum Pidana II, Tinta Mas, Surabaya, 1987

Joko Prakoso, Hukum Penitensier Indonesia, Liberty Yogyakarta, 1988 Lamintang dan Simons, Kitab Pelaran Hukum Pidana, Pioner, Bandung, 1992

Efi Laila Kholis, Pembayaran Uang Pengganti Dalam Perkara Korupsi, Solusi Publishing, Depok, 2010 